\title{
The economic consequences of ENSO events for agriculture
}

\author{
Richard M. Adams ${ }^{1, *}$, Chi-Chung Chen², Bruce A. McC arl'², Rodney F. Weiher ${ }^{3}$ \\ ${ }^{1}$ Department of Agricultural and Resource Economics, Oregon State University, Corvallis, Oregon 97331, USA \\ ${ }^{2}$ Department of Agricultural Economics, Texas A\&M University, C ollege Station, Texas 77843, USA \\ ${ }^{3}$ Office of Policy and Strategic Planning, National O ceanic and A tmospheric Administration, \\ United States Department of C ommerce, Washington DC 20230, USA
}

\begin{abstract}
Climate is the primary determinant of agricultural productivity. It is believed that in many parts of the world, including the United States, much of the year-to-year variation in climate can be traced to the EI Niño-Southern Oscillation phenomenon. In 1997-98 the world experienced a severe El $\mathrm{Niño} \mathrm{event} \mathrm{and} \mathrm{this} \mathrm{was} \mathrm{followed} \mathrm{by} \mathrm{a} \mathrm{strong} \mathrm{La} \mathrm{Niña} \mathrm{in} \mathrm{1998-99.} \mathrm{This} \mathrm{paper} \mathrm{develops} \mathrm{estimates} \mathrm{of} \mathrm{the}$ economic consequences of such events on US agriculture using a stochastic economic model of the US agricultural sector. Both phases result in economic damages to US agriculture - a \$1.5 to \$1.7 billion Ioss for EI Niño and a $\$ 2.2$ to $\$ 6.5$ billion loss for La Niña. The range in these damage estimates reflects assumptions concerning the relationship between yields and ENSO weather patterns and how farmers respond to these potential yield differentials.
\end{abstract}

KEY WORDS: ENSO events · Economic effects · Agriculture

\section{INTRODUCTION AND BACKGROUND}

Climate is the primary determinant of agricultural productivity. An important aspect of climate in terms of human well being involves the effects on agriculture of seasonal and interannual variations in temperature and precipitation. The effects of drought and flooding provide the clearest evidence of the vulnerability of agriculture and food supplies to seasonal variations in temperature and precipitation. However, less dramatic climate variations also are reflected in agricultural production, prices and profits. It is hypothesized that in many parts of the world, including the United States, much of the year-to-year variation in climate can be traced to the EI Niño-Southern Oscillation (ENSO) phenomenon.

The ENSO label refers to a quasi-periodic redistribution of heat and momentum in the tropical Pacific Ocean. In broad terms, one can characterize ENSO as a varying shift between a normal or neutral phase and

*E-mail: richard.m.adams@orst.edu
2 extreme phases: EI Niño and La Niña (sometimes called EI Viejo). In recent years, the ability to forecast ENSO events, in particular the occurrence of EI Niño events, has improved (Cane et al. 1986, Barnett et al. 1988, Bengtsson et al. 1993). Recent research also indicates that the frequency of the extreme phases of ENSO events are likely to increase with warming of the earth's atmosphere (Timmermann et al. 1999). Forecasts of ENSO events have potential economic value because they can stimulate actions that mitigate adverse consequences or take advantage of potential gains from an ENSO phase.

The 1997-98 El Niño is regarded as one of the most severe in the past decade and equal to the strong $\mathrm{EI}$ Niño of 1982-83. The physical effects of this latest EI Niño were felt through much of the Southwestern and Eastern United States, with heavy rains and flooding throughout the winter and spring in California and Arizona and a mild, but wet winter and spring in the northeast. Evidence from weekly crop prices suggests that disruptions of certain high-value spring crops in California imposed substantial costs. For example, reductions in California strawberry marketings in the 
spring of 1998, due primarily to flooding, resulted in losses to consumers of over $\$ 15$ million compared to 1997 prices, and nearly $\$ 100$ million compared to the average price for the previous $10 \mathrm{yr}$, based on estimates of seasonal demand relationships for strawberries (Adams 1998).

By the summer of 1998 there was evidence that the waning 1997-98 El Niño was moving rapidly into a La Niña phase, with a dramatic cooling of ocean surface temperatures in the southern Pacific Ocean. Like EI Niño events, La Niña events also have specific regional 'footprints', but with a general reversal of the weather patterns observed during typical El Niños (e.g. colder but drier winters in the western US). These La Niña events also have effects on agricultural crop yields (Legler et al. 1999).

The damages associated with the recent EI Niño demonstrate that ENSO events have potential economic consequences for agriculture and other sectors of the economy; recent studies show that the use of forecasts of these events has economic value (A dams et al. 1995, Costello et al. 1998, Solow et al. 1998). The agricultural values for such forecasts have been esti-

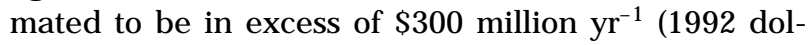
lars). However, the actual damages from a given ENSO event will be greater than the value of the forecasts since in general not all damages can be avoided and forecasts are not perfect. Estimates of actual or prospective damages from ENSO events can be useful to policy makers in determining whether such events are important relative to other natural processes and whether the potential damages from a future event, such as the developing La Niña, merit vulnerabilityreducing actions.

\section{OBJECTIVES}

The overall objective of this paper is to develop estimates of the economic consequences of the recent (1997-98) El Niño event and to assess possible effects of the 1998-99 La Niña event on US agriculture. At the time of this assessment, both estimates are prospective, in that the final effects of the 1997-98 El Niño on agriculture will not be understood until final data of the 1998 harvests and yields become available. Similarly, the full effects of a 1998-99 La Niña on agriculture will not be realized for at least $12 \mathrm{mo}$. However, the historical climatological record, which includes years reflecting all 3 ENSO phases, provides some indication as to how weather in agricultural production areas has varied during such ENSO phases. These weather data can then be used to estimate yield effects of ENSO events.

The assessment uses 2 approaches to understand the implications of weather on crop yields. In the first, his- torical (actual) weather and crop yield occurrences, measured as departures from normal (long-term average) yields, are used here as a measure of the effects of the most recent EI Niño and La Niña events. In addition, estimates of yield changes for such ENSO events, taken from a recent study by Solow et al. (1998), are also used. The Solow et al. (1998) study involved modeled (simulated) crop yield changes. The use of modeled yields is a common practice in such research. As discussed in Solow et al. (1998) and Legler et al. (1999), the use of modeled or simulated yields is motivated by the belief that this approach may provide a clearer picture than historical yield deviations of the effects of weather, given that historical data on crop yields may contain effects from other factors, such as crop diseases, changes in crop acreage or other non-weather phenomenon.

The yield changes for EI Niño, Neutral and La Niña events arising from both the historical record and model simulations are used as input into an economic assessment framework. The key feature of this framework is an economic model of the US agricultural sector. This economic sector model is used to translate the crop yield effects of these ENSO events into changes in prices, crop supplies, and the welfare of consumers and producers. Procedures underlying this simulation of ENSO events, including data and the economic model, are discussed in more detail in the following section. The subsequent section presents results of these simulated ENSO events. Implications of these estimates and conclusions are presented in the final section of this report.

\section{PROCEDURES AND MODELS}

This assessment of the damages from ENSO events involves a 2-stage process. In the first stage, the effects on crop yields of the changes in weather patterns due to ENSO phases are measured using estimates from both crop biophysical simulation models and historical yield data. The second stage incorporates these yield differences into an economic assessment framework in order to assess the aggregate economic damages of the 2 ENSO events.

\subsection{Crop yield changes}

The first set of yield estimates are taken from Solow et al. (1998) and are based on output from a crop simulation model. Specifically, estimates of the implications of weather changes from EI Niño and La Niña events on the yields of 8 field crops (corn, wheat, soybeans, cotton, barley, sorghum, oats and hay) were developed 
using a biophysical simulation model called Erosion Productivity Impact Calculator or EPIC (Williams et al. 1984, 1989). EPIC has been used in numerous studies for a variety of purposes and has gained popularity across disciplines in agriculture. EPIC has been shown to provide reasonable simulations of crop yields in previous ENSO studies (Bryant et al. 1992). Details of the EPIC application to ENSO events can be found in Adams et al. (1995) and Solow et al. (1998). Specific crop yield data for ENSO phases are reported in Solow et al. (1998) and Legler et al. (1999). The weather patterns underlying the yield estimates predicted by the EPIC models represent crop growing season weather for El Niño and La Niña events (averaged over years categorized as EI Niño and La Niña). Thus, these yield predictions do not correspond to any particular ENSO weather year.

The second approach to estimating consequences of ENSO phases on yields is based on $25 \mathrm{yr}$ (1972 to 1996) of crop yield data for all crops included in the economic model (the eight listed above plus citrus and some minor crops). The yield data are taken from US Department of Agriculture (1997). These yield data are first detrended (to remove the effects of technological change and acreage shifts on yields) and then yield estimates are projected for each year. In turn, the deviations between the projected and actual yields are recorded as a percentage change from the projected yields. Finally these deviations were applied to the 1997 yield projection to obtain a joint probability distribution across 63 US regions based on the 25 historic weather events. This distribution reflects, among other factors or influences, the variation due to weather, including each ENSO phase.

\subsection{Economic modeling procedures}

The economic modeling procedure consists of a general modeling framework, reflecting the decision problem facing a farmer when confronted with uncertain weather conditions, and a specific economic model of the US agricultural sector, which then translates the implications of those crop decisions on yields into their economic consequences. This modeling framework and the sector model nested within this framework are discussed below.

\subsubsection{Conceptual stochastic model}

It is well documented that crop yields vary spatially and temporally, due to variations in weather, diseases, pest infestations and other plant stressors. Of importance here is the observation that regional crop yields vary according to ENSO event strength (Legler et al. 1999). Since planting decisions are made well in advance of actual growing season weather, knowledge of yield outcomes is imperfect when such planting decisions are made. Therefore, the modeling framework includes a yield distribution (following the modeling approach explained in Lambert et al. 1995). At the time of planting, a number of yield states of nature can occur but the farmer does not know which one will occur. In fact, farmers must choose their crop mixes considering the weather probability distribution without knowledge of which exact weather event will occur. The model depicts this using a 2-stage formulation as in Dantzig (1955), Cocks (1968), McCarl \& Parandvash (1988), or Solow et al. (1998).

This assessment differs from the Solow et al. (1998) and Adams et al. (1995) analyses (which used essentially the same model and approach) in terms of the way ENSO events are incorporated and the way that the events are valued. Namely, in the prior work a 3-state definition of ENSO phase was used for the stochastic outcomes (EI Niño, La Niña, Neutral). Here we do not use ENSO phase in defining states but rather define states for each of 25 historically observed years on which we have data (1972 to 1996). We also do not factor in producer reaction to ENSO phase information (i.e. in the prior work the value of forecasting was derived by examining the benefits of producers making crop mix decisions based on an anticipation or forecast of a particular ENSO phase). Here we assumed the producer decision was made in the face of an 'average weather' expectation considering the probability distribution of yields represented by the $25 \mathrm{yr}$ distribution, with each of the yield events being equally likely. In turn we derived the costs of the severe EI Niño event by comparing economic returns under a severe EI $\mathrm{Niño}$ (e.g. 1982-83) with the economic returns from an average year. This results in an estimate of the economic effects that farmers and the agricultural sector would realize when the farmers expect 'average' weather but instead an ENSO event of the strength of the 1982-83 event occurs.

The general modeling framework is summarized by the following equations. The objective function is:

$$
\begin{aligned}
& \text { Max }-\sum_{\mathrm{j}} \sum_{\mathrm{k}} \mathrm{g}_{\mathrm{jk}} \mathrm{X}_{\mathrm{jk}} \\
& -\sum_{\mathrm{k}} \sum_{\mathrm{r}} \int \alpha\left(\mathrm{R}_{\mathrm{rk}}\right) \mathrm{dR} \mathrm{R}_{\mathrm{rk}}
\end{aligned}
$$

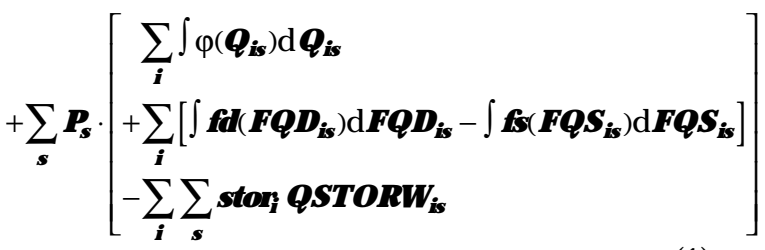


Parameters are given in lower case or Greek, while variables are given in upper case; they are defined as follows: i: index of commodities, j: index of production process, $\mathrm{k}$ : index of US regions, $r$ : index of resources, $s$ : index of the state defining alternative yields, $p_{s}$ : the probability that yield state $s$ arises, $Q_{i s}$ : consumption of ith product under yield state $\mathrm{S}, \mathrm{FQD}_{\text {is }}$ : excess demand quantity for commodity $\mathrm{i}$ under yield state $\mathrm{S}, \mathrm{FQS}_{\text {is }}$ : excess supply quantity for commodity $i$ under yield state $S, R_{r k}$ : factor supply for US region $k$ of resource $r$, $\varphi\left(Q_{i s}\right)$ : inverse US demand function for commodity $i$ consumed under yield state $\mathrm{S}, \alpha\left(\mathrm{R}_{\mathrm{rk}}\right)$ : inverse US factor supply function for factor $r$ in US region $k, f d\left(F Q D_{i s}\right)$ : inverse excess demand function for commodity $i$, fs $\left(F Q S_{i s}\right)$ : inverse excess supply function for commodity $\mathrm{i}, \mathrm{g}_{\mathrm{jk}}$ : cost of $\mathrm{jth}$ production process per acre in US region $\mathrm{k}, \mathrm{X}_{\mathrm{jk}}$ : acreage of $\mathrm{jth}$ production process in US region $k$, stor $r_{i}$ storage cost in the US for commodity $i$, and QSTORW is: $_{\text {: }}$ quantity withdrawn from storage of commodity i under yield state $\mathrm{s}$.

The first 2 lines of Eq. (1) (ignoring for now the stochastic, yield-state dimension) contain the perfectly elastic production costs associated with production process $\mathrm{j}\left(\mathrm{g}_{\mathrm{jk}} \mathrm{X}_{\mathrm{jk}}\right)$ less the area under the regional $(\mathrm{k})$ factor supply curves. The next 2 lines are the area under the US national demand equations $\left[\int \varphi\left(Q_{i s}\right) d Q_{i s}\right]$ and the area under the rest of the world (ROW) excess demand curves minus the area under excess supply curve for commodity i. Finally, the last line gives the cost of storage.

The model is stochastic in that the yields occur with varying frequency and consequences. It also is a multiple-stage model in that all terms and variables but those in the first 2 lines are yield state dependent, while the first line is not. This assumes that crop mix and factor use are set before the specific yield state is known, but that demand and trade are set afterward, given knowledge of production (for more explanation see Lambert et al. 1995). The third line includes multiplication by the relevant probabilities. This renders the objective function a maximization of expected welfare and also results in production choices where expected marginal revenue is equated with marginal cost.

The model contains commodity balances in the US as follows:

$$
\begin{aligned}
-\sum_{\mathrm{j}} \sum_{\mathrm{k}}\left[\left(\mathrm{y}_{\mathrm{ijk}}+\mathrm{yr}_{\mathrm{ijks}}\right)\right. & \left.\cdot \mathrm{X}_{\mathrm{jk}}\right] \\
& -\mathrm{FQS}_{\mathrm{is}} \\
& -\mathrm{QSTORW}_{\mathrm{is}} \\
& +\mathrm{Q}_{\mathrm{is}} \\
& +\mathrm{FQD}_{\text {is }} \\
& +\mathrm{QSTORA}_{\mathrm{is}} \leq \text { forall i,s }
\end{aligned}
$$

where supply from production on average $(y)$ plus the difference due to yield state $(y r)$ times acreage $(X)$ plus that imported (FQS) plus withdrawals from storage (QSTORW) is balanced against domestic demand (Q), exports (FQD) and additions to storage (QSTORA) for a commodity (i) under yield state (s).

The factor constraint for region $\mathrm{k}$ in the US is

$$
\sum_{j} f_{r j k} X_{j k}-R_{r k} \leq 0 \text { for all } k, r
$$

where $f_{r j k}$ is the resource usage per acre for $j$ th production processing in US region $\mathrm{k}$ for resource $\mathrm{r}$. This equation balances factor supply ( $\mathrm{R}$ ) against usage by production ( $\mathrm{fX}$ ) in US region $\mathrm{k}$ for factor $\mathrm{r}$.

The storage balance is

$$
\sum_{\mathrm{s}} \mathrm{P}_{\mathrm{S}}\left(\mathrm{QSTORW}_{\text {is }}-\mathrm{QSTORA}_{\text {is }}\right)=0 \text { for all } \mathrm{i}
$$

where probabilistically weighted net additions and withdrawals are equal.

\subsubsection{Empirical model of the agricultural sector}

An empirical US agricultural sector model (hereafter called the Agricultural Assessment Model or ASM) forms the core of the stochastic model. ASM is based on the work of Baumes (1978) which was later modified and expanded by Burton \& M artin (1987), Adams et al. (1986), Chang et al. (1992) and Lambert et al. (1995).

Conceptually, ASM is a price-endogenous, mathematical programming model of the type described in M cCarl \& Spreen (1980). Constant elasticity demand curves are used to represent domestic consumption and export demands as well as input and import supplies. Elasticities were assembled from a number of sources, including US Department of Agriculture (1982).

ASM is designed to simulate the effects of changes in agricultural resource usage or the resources available, in turn determining the implications for prices, quantities produced, consumers' and producers' welfare, exports, imports and food processing. In doing this the model considers production, processing, domestic consumption, imports, exports and input procurement. The model distinguishes between primary and secondary commodities, with primary commodities being those directly produced by the farms and secondary commodities involve processing. For production purposes, the US is disaggregated into 63 geographical subregions (Table 1). Each subregion possesses different endowments of land, labor and water as well as crop yields. Agricultural production is described by a set of regional budgets for crops and livestock. ASM crop mix is required to appear in a convex combination of historical crop mix proportions following McCarl 
Table 1. Regional and subregional disaggregation in the US agricultural sector model (ASM)

\begin{tabular}{|c|c|c|}
\hline $\begin{array}{l}\text { Northeast } \\
\text { Connecticut } \\
\text { Delaware } \\
\text { Maine } \\
\text { Maryland } \\
\text { Massachusetts } \\
\text { New Hampshire } \\
\text { New J ersey } \\
\text { New York } \\
\text { Pennsylvania } \\
\text { Rhode Island } \\
\text { Vermont }\end{array}$ & $\begin{array}{l}\text { Cornbelt } \\
\text { North Illinois } \\
\text { South Illinois } \\
\text { North Indiana } \\
\text { South Indiana } \\
\text { North East Iowa } \\
\text { Central Iowa } \\
\text { South Iowa } \\
\text { West lowa } \\
\text { Missouri } \\
\text { North East Ohio } \\
\text { North West Ohio } \\
\text { South Ohio }\end{array}$ & $\begin{array}{l}\text { Southern Plains } \\
\text { Oklahoma } \\
\text { Texas Central Blacklands } \\
\text { Texas Coast Bend } \\
\text { Texas East } \\
\text { Texas Edwards Plateau } \\
\text { Texas High Plains } \\
\text { Texas Rolling Plains } \\
\text { Texas South } \\
\text { Texas Trans Pecos }\end{array}$ \\
\hline $\begin{array}{l}\text { M ountain } \\
\text { Arizona } \\
\text { Colorado } \\
\text { Idaho } \\
\text { Montana } \\
\text { New M exico } \\
\text { Utah } \\
\text { Wyoming } \\
\text { Nevada }\end{array}$ & $\begin{array}{l}\text { Lake States } \\
\text { Michigan } \\
\text { Minnesota } \\
\text { Wisconsin }\end{array}$ & $\begin{array}{l}\text { Southeast } \\
\text { Alabama } \\
\text { Florida } \\
\text { Georgia } \\
\text { South Carolina }\end{array}$ \\
\hline $\begin{array}{l}\text { Northern Plains } \\
\text { Kansas } \\
\text { Nebraska } \\
\text { North Dakota } \\
\text { South Dakota }\end{array}$ & $\begin{array}{l}\text { Delta States } \\
\text { Arkansas } \\
\text { Louisiana } \\
\text { Mississippi }\end{array}$ & $\begin{array}{l}\text { Pacific } \\
\text { North California } \\
\text { South California } \\
\text { Oregon } \\
\text { Washington }\end{array}$ \\
\hline $\begin{array}{l}\text { Appalachian } \\
\text { Kentucky } \\
\text { North Carolina } \\
\text { Tennessee } \\
\text { Virginia } \\
\text { West Virginia }\end{array}$ & & \\
\hline
\end{tabular}

(1982). Marketing and other costs are added to the budgets following the procedure described in Fajardo et al. (1981) such that the marginal cost of each budget equals the marginal revenue. ASM also contains a set of national processing budgets which uses crop and livestock commodities as inputs. There are also import supply functions from the ROW for a number of commodities. The demand sector of the model is constituted by the intermediate use of all the primary and secondary commodities, domestic consumption use and exports.

There are 41 primary commodities in the model. These are listed in Table 2 . The primary commodities are chosen to depict the majority of agricultural production, land use and economic value in US agriculture. They can be grouped into crops and livestock. The model incorporates processing of the primary commodities. The production of primary commodities is regionally specific, but the processing of secondary commodities is done in the overall aggregate sector. There are 45 secondary commodities that are pro- cessed in the model (Table 3). These commodities are chosen based on their linkages to agriculture. Some primary commodities are inputs to the processing activities, yielding secondary commodities, and certain secondary products (feeds and by-products) are in turn inputs into primary agricultural commodities, such as livestock.

Three land types (crop land, pasture land, and land for grazing on an animal unit month basis) are specified for each region. Land is available according to a regional price elastic supply schedule, with a rental rate as reported in US Department of Agriculture farm real estate statistics. The labor input includes family and hired labor. A region-specific reservation wage and maximum amount of family labor available reflect the supply of family labor. The supply of hired labor consists of a minimum inducement wage rate and a subsequent price elastic supply. Water comes from surface-water and pumped groundwater sources. Surface water is available at a constant price, but pumped water is supplied according to a price elastic supply schedule.

\section{RESULTS}

The 2-stage assessment procedure defined above can be viewed as a set of 'experiments' conducted within the economic framework to measure the potential consequences on US agriculture of as yet unrealized weather events. In this case, these weather events are intended to mimic the effects of a major EI Niño in 1997-98 and a La Niña event in 1998-99. These experiments provide an indication of how 2 strong ENSO events affect the aggregate (national level) economic welfare of the agricultural sector. These experiments also make evident the sensitivity of the economic estimates to the approach used to project yield effects.

One set of experiments is needed to create the base case or benchmark economic values against which the EI Niño and La Niña experiments will be evaluated. The results from this base case experiment reflect a range of weather and yield conditions. Specifically, the yield and subsequent economic consequences elicited here reflect historical frequencies of each ENSO phase. To capture these, the ASM economic model is run (solved) under a series of uncertain events ( 3 in the EPIC-based analysis, and 25 in the 'historical' yield case) based on the long-run probability of each of the ENSO phases occurring. These probability-weighted results from the ASM are used to determine the average economic conditions (or naive expectations on the 
Table 2. Primary commodities in the ASM . LW: live weight. GCAU: grain consuming animal unit

\begin{tabular}{|llllll|}
\hline & Crop commodity & Units & & Livestock commodity & Units \\
\hline 1 & Cotton & Bales & 20 & Milk & Cwt \\
2 & Corn & Bushel & 21 & Cull dairy cows & Head \\
3 & Soybeans & Bushel & 22 & Cull dairy calves & Head \\
4 & Wheat & Bushel & 23 & Cull beef cows & Cwt, LW \\
5 & Sorghum & Bushel & 24 & Calves & Cwt, LW \\
6 & Rice & Cwt & 25 & Yearlings & Cwt, LW \\
7 & Barley & Bushel & 26 & Non-fed beef & Cwt, LW \\
8 & Oats & Bushel & 27 & Fed beef & Cwt, LW \\
9 & Silage & Ton & 28 & Veal calves & Cwt, LW \\
10 & Hay & Ton & 29 & Cull sows & Cwt, LW \\
11 & Sugar cane & 1000 lbs & 30 & Hogs & Cwt, LW \\
12 & Sugar beets & 1000 lbs & 31 & Feeder pigs & Cwt, LW \\
13 & Potatoes & Cwt & 32 & Cull ewes & Cwt, LW \\
14 & Fresh tomatoes & 25 lb boxes & 33 & Wool & Cwt \\
15 & Processed tomatoes & Tons & 34 & Feeder lambs & Cwt, LW \\
16 & Fresh oranges & 90 lb boxes & 35 & Slaughter lambs & Cwt, LW \\
17 & Processed oranges & Tons & 36 & Unshorn lambs & Cwt, LW \\
18 & Fresh grapefruits & 85 lb boxes & 37 & Wool subsidy & \$ \\
19 & Processed grapefruits & 85 lb boxes & 38 & Other livestock & GCAU \\
& & & 39 & Broilers & Cwt, LW \\
& & & 40 & Turkeys & Cwt, LW \\
& & & 41 & Eggs & Thousand dozen \\
\hline
\end{tabular}

Table 3. Secondary commodities in the ASM. CW: carcass weight

\begin{tabular}{|c|c|c|c|c|c|}
\hline & Commodity & Units & & Commodity & Units \\
\hline 1 & Soybean meal & Cwt & 24 & Cow protein feed & 1000 lbs \\
\hline 2 & Soybean oil & 1000 lbs & 25 & Sheep protein feed & Cwt \\
\hline 3 & Raw sugar & $1000 \mathrm{lbs}$ & 26 & Egg protein feed & $\mathrm{lb}$ \\
\hline 4 & Refined sugar & $1000 \mathrm{lbs}$ & 27 & Broiler protein feed & $\mathrm{Ib}$ \\
\hline 5 & Corn starch & $1000 \mathrm{lbs}$ & 28 & Turkey protein feed & $\mathrm{lb}$ \\
\hline 6 & Corn gluten feed & $1000 \mathrm{lbs}$ & 29 & Fluid milk & $\mathrm{Ib}$ \\
\hline 7 & Corn oil & $1000 \mathrm{lbs}$ & 30 & Skim milk & $\mathrm{Ib}$ \\
\hline 8 & Ethanol & $1000 \mathrm{lbs}$ & 31 & Non-fat dry milk & $\mathrm{lb}$ \\
\hline 9 & High fructose corn syrup & $1000 \mathrm{lbs}$ & 32 & Cream & $\mathrm{Ib}$ \\
\hline 10 & Corn syrup & $1000 \mathrm{lbs}$ & 33 & Butter & $\mathrm{lb}$ \\
\hline 11 & Dextrose & $1000 \mathrm{lbs}$ & 34 & Ice cream & Cwt \\
\hline 12 & Confectioneries & $1000 \mathrm{lbs}$ & 35 & American cheese & Cwt \\
\hline 13 & Beverages & $1000 \mathrm{lbs}$ & 36 & Other cheese & Cwt \\
\hline 14 & Baked goods & 1000 lbs & 37 & Cottage cheese & Cwt \\
\hline 15 & Canned goods & 1000 lbs & 38 & Fed beef & Cwt, CW \\
\hline 16 & Dried potatoes & Cwt & 39 & Non-fed beef & Cwt, CW \\
\hline 17 & Chipped potatoes & Cwt & 40 & Veal & Cwt, CW \\
\hline 18 & Frozen potatoes & Cwt & 41 & Pork & Cwt, CW \\
\hline 19 & Feed grains & $1000 \mathrm{lbs}$ & 42 & Chicken & Cwt, CW \\
\hline 20 & Dairy concentrate & 1000 lbs & 43 & Whole turkeys & Cwt, CW \\
\hline 21 & Swine protein feed & 1000 lbs & 44 & Orange juice & 1000 gals \\
\hline 22 & Cattle protein feed & $1000 \mathrm{lbs}$ & 45 & Grapefruit juice & 1000 gals \\
\hline 23 & Range cubes & 1000 lbs & & & \\
\hline
\end{tabular}

part of the farmer) from which the EI Niño and La Niña economic effects will then be inferred.

In the EPIC-based analysis, the EI Niño and La Niña results do not correspond to a particular year, rather they represent weather conditions (and resultant yield changes) that are intended to mimic EI Niño or La Niña weather. In the 'historical' yields case, 2 specific time periods from the $25 \mathrm{yr}$ record are used to portray possible effects of each phase: 1982-83 for the EI Niño and 1988-89 for La Niña. Both time periods reflect years identified by climatologists as strong phases of each event. The economic consequences of these ENSO 
events under this latter approach are measured as departures from the average yields across all ENSO phases contained in the $25 \mathrm{yr}$ record (again, these long-term yields are assumed to represent farmers' expectations concerning the next season's yields).

The results of these experiments are provided in Tables $4 \& 5$. In Table 4, results from the EPIC-based simulations of each ENSO phase or event are reported. As is evident from the table, both phases result in economic damages relative to the naive expectations case of an average year in terms of weather and yields. These losses are $\$ 2.5$ billion for EI Niño and $\$ 6.5$ billion for La Niña. For the analysis based on historical yields (Table 5), both ENSO phases again show losses (economic damages) although of a smaller magnitude. Here, the economic damages of EI Niño and La Niña are $\$ 1.7$ and $\$ 2.3$ billion, respectively.

The differences between the 2 approaches to yield estimation (modeled vs historical) is substantial, with the EPIC yield changes greater than yield changes for the historical data. This is most pronounced in the case of La Niña, for which the resulting economic damages are $\$ 2.3$ billion from historical yields versus $\$ 6.5$ billion from the EPIC-based yields. The EPIC yields are projections under weather patterns meant to simulate ENSO conditions in various regions. Other influences and stressors are held constant. The historical yields are actual or realized yields for given years (in this case, the 1982-83 and 1988-89 crop years). As such, the historical yields reflect the range of weather, econo-

Table 4. Estimates of damages from El Niño and La Niña events using simulated crop yield changes. The weather patterns used as inputs to the EPIC model reflect or simulate a 'strong' ENSO event. Economic consequences (damages) reported here are measured against an average or 'base case' derived by using historical frequencies of all 3 ENSO phases:

EI Niño at 0.230, La Niña at 0.25 and Neutral at 0.512

\begin{tabular}{|lc|}
\hline ENSO event & $\begin{array}{l}\text { Economic consequences } \\
\text { (millions of 1990 dollars) }\end{array}$ \\
\hline El Niño & -2543 \\
La Niña & -6455 \\
\hline
\end{tabular}

Table 5. Estimates of strong EI Niño and La Niña using historical crop yields. The historical analogues used to represent the 1997-98 El Niño and the 1998-99 La Niña are the 1982-83

EI Niño and the 1988-89 La Niña, respectively

\begin{tabular}{|lc|}
\hline ENSO event & $\begin{array}{l}\text { Economic consequences } \\
\text { (millions of 1990 dollars) }\end{array}$ \\
\hline EI Niño & -1739 \\
La Niña & -2247 \\
\hline
\end{tabular}

mic, and other influences of that crop year. To the extent that these other weather and economic influences are favorable (in the sense that they are yieldenhancing), they may offset or mitigate some of the direct negative ENSO effects simulated in the EPIC analysis.

As expected, the damages measured here for a given ENSO phase exceed the value of improved forecasts reported in Solow et al. (1998) (because not all damages can be mitigated, even with a perfect forecast). While the economic damages from the EPIC-based analysis are greater than those from historical data, the important finding is that these events translate into economic damages for agriculture under both sets of assumptions regarding yield changes. It is also worth noting that the optimization nature of the economic model used here results in estimates from both sets of yield changes that reflect some internal actions (such as changes in input and output use patterns in response to price changes) to offset or mitigate the negative consequences of the changes in yields. Thus, the estimates are lower bounds on damages.

The overall implication of these findings regarding ENSO phases is not surprising; extreme events, whether driven by EI Niño or La Niña weather patterns, have adverse consequences for agriculture (at the national level). These estimates are of damages from a given event (and not the value to the agricultural sector of ENSO forecasts, as in Solow et al. 1998) However, to the extent that some of these agriculture effects can be mitigated or offset by planning, the results confirm that there is value in forecasting such ENSO phenomena.

\section{CONCLUSIONS}

ENSO events have varying effects on temperature and precipitation across agricultural regions of the US. For some regions, these changes in seasonal weather may be beneficial. However, for other regions the effects can be dramatic and severe, such as the floods in the southwest during the spring of 1998 . These changes in seasonal weather patterns can translate into economic effects if crop yields are reduced (or increased) from expected or average levels.

The assessment framework used here combines possible weather-induced yield change information with an economic model of the US agricultural sector to estimate the economic consequences of alternative ENSO states. Of specific concern are the $\mathrm{EI} \mathrm{Niño}$ event of 1997-98 and the La Niña event of 1998-99. The analyses may be viewed as a set of 'what-if' experiments incorporating alternative ENSO states and their respective yield manifestations. 
The results of the experiments performed here indicate that overall the effects of both extreme ENSO phases are negative for US agriculture. M easured as departure from normal (not El Niño or La Niña) yields, the consequences vary from approximately $\$ 1.5$ to $\$ 6.5$ billion in losses in 1990 dollars. The range reflects assumptions concerning how yields are estimated and whether it is an El Niño or La Niña event. La Niña events appear to result in greater losses than EI Niño. The importance of the yield evidence used in such analysis is underscored by the large differences in economic consequences observed between the use of historical crop yields and the modeled crop yields.

The estimates reported here must be viewed in the context in which they are generated. As estimates from a modeling exercise, the numbers reflect a series of embedded assumptions and are conditional on the quality of data used in the economic modeling and in the generation of the yields used to capture the various ENSO phases. The major conclusion is that extreme weather events, such as the ENSO events, do impose costs on agriculture and consumers. The magnitude of the cost estimates supports concerns about the likely increase in extreme weather phenomena under a warming global atmosphere.

Acknowledgements. Technical paper no. 11594 of the Oregon State Agricultural Experiment Station. Partial funding support provided by the National Oceanic and Atmospheric Administration, US Department of Commerce. We appreciate the helpful comments of 2 reviewers on an earlier version of this paper.

\section{LITERATURE CITED}

Adams RM (1998) ENSO Effects of the 1997-98 El Niño on strawberry and other vegetable demand and prices. Unpublished manuscript, Oregon State University, Corvallis

Adams RM, Hamilton SA, McCarl BA (1986) The benefits of air pollution control: the case of ozone and US agriculture. Am J Agric Econ 68:886-894

Adams RM, Bryant KJ , McCarl BA, Legler DM, O'Brien J , Solow A, Weiher R (1995) Value of improved long-range weather information. Contemp Econ Policy XIII:10-19

Barnett T, Graham N, Cane M, Zebiak S, Dolan S, O'Brien J , Legler D (1988) On the prediction of the EI Niño 1986-1987. Science 241:192-196

Baumes H (1978) A partial equilibrium sector model of US agriculture open to trade: a domestic agricultural and agricultural trade policy analysis. PhD thesis, Purdue University, West Lafayette, IN

Editorial responsibility: Brent Yarnal, University Park, Pennsylvania, USA
Bengtsson L, Schlese V, Roeckner E, Latif M, Barnett TP, Graham N (1993) A two-tiered approach to long-range climate forecasting. Science 261:1026-1029

Bryant KJ , Benson VW, Kiniry J R, Williams J R, Lacewell RD (1992) Simulation of corn yield response to irrigation timing: validation of the EPIC model. J Prod Agric 5: 230-232

Burton RO, Martin MA (1987) Restrictions on herbicide use: an analysis of economic impacts on US agriculture. North Central J Agric Econ 9:181-194

Cane MA, Zebiak SE, Dolan SC (1986) Experimental forecasts of EI Niño. Nature 321:827-832

Chang CC, McCarl BA, Mjelde JW, Richardson JW (1992) Sectoral implications of farm program modifications. Am J Agric Econ 74:38-49

Cocks KD (1968) Discrete stochastic programming. Manage Sci 15:72-79

Costello CJ , Adams RM, Polasky S (1998) The value of EI $\mathrm{N}$ iño forecasts in the management of salmon: a stochastic dynamic assessment. AmJ Agric Econ 80:765-777

Dantzig G (1955) Linear programming under uncertainty. Manage Sci 1:197-206

Fajardo D, M cCarl BA, Thompson RL (1981) A multicommodity analysis of trade policy effect: the case of Nicaraguan agriculture. AmJ Agric Econ 63:23-31

Lambert DK, McCarl BA, He Q, Kaylen MS, Rosenthal W, Chang CC, Nayda WI (1995) Uncertain yields in sectoral welfare: an application to global warming. J Agric Appl Econ 27:423-436

Legler DM, Bryant KJ, O'Brien JJ (1999) Impact of ENSOrelated climate anomalies on crop yields in the U.S. Clim Change 42:351-375

McCarl BA (1982) Cropping activities in agricultural sector models: a methodological proposal. Am J Agric Econ 64: 768-772

McCarl BA, Parandvash GH (1988) Irrigation development versus hydroelectric generation: can interruptible irrigation play a role? Western J Agric Econ 13:267-276

McCarl BA, Spreen TH (1980) Price endogenous mathematical programming as a tool for sector analysis. Am J Agric Econ 62:87-102

Norton R, Schiefer GW (1980) Agricultural sector programming models: a review. Eur Rev Agric Econ 7:229-264

Solow A, Adams R, Bryant K, Legler D, O'Brian J, M cCarl B, Nayda W, Weiher R (1998) The value of ENSO forecasts: the case of US agriculture. Clim Change 39:47-60

Timmermann A, Oberhuber J, Backer A, Each M, Latif M, Roeckner E (1999) ENSO response to greenhouse warming. Nature 398:694-697

US Department of Agriculture (1982) FEDS budgets. Economic Research Service, Washington, DC

US Department of Agriculture (1997) Agricultural Statistics, 1997. US Government Printing Office, Washington, DC

Williams J R, J ones CA, Dykem PT (1984) A modeling approach to determining the relationship between erosion and soil productivity. Am Soc Agric Eng 27:129-144

Williams J R, J ones CA, Kiniry J R, Spanel DA (1989) The EPIC crop growth model. Am Soc Agric Eng 32:497-511

Submitted: March 31, 1999; Accepted: October 11, 1999, Proofs received from author(s): N ovember 22, 1999 